\title{
Representations of Reading in Brazilian Contemporary Children's Literature
}

\section{Maria da Conceição Carvalho}

\section{Alessandra Santana da Silva}

\section{Tatiane Meire Campos}

School of Information Science /UFMG

Av. Antônio Carlos, 6627 - CEP:31270 -901 Belo Horizonte - MG

Brazil

Phone: +553134096124

+553125313324

daccar@gmail.com

\begin{abstract}
This article is part of a broader study that aims at comparing the role assigned to reading in terms of fictional creation for children and youngsters in Brazil and Argentina from 1991 to 2012. The results here presented are exclusively referring to Brazil. $A$ sample of 10 books taken from publishers catalogues who print child/youth literature was analyzed. Based on Serge Moscovici's concept of social representation it was possible to demonstrate that less than half of the narratives represent the daily reading still linked to a pedagogizing concept of the child genre, with openly utilitarian purposes. However, a significant number of narratives show good aesthetic level, presenting reading and the formation of readers in a thought-provoking and problematizing way.
\end{abstract}

Keywords: Children's literature; Social representations; School libraries; Brazilian Children's literature, Brasil

\section{Background and objectives}

UNESCO proposes three factors that are necessary for readers to exist in a country:

1. The book should be in a privileged place in the national imagination

2. There must be for readers families

3. Schools must know how to form readers

We thought of developing research to verify to what extent the first-mentioned factor is true in Brazilian culture since the two other have been much explored by studies related to the History and Sociology of education in Brazil, not always with positive results. 
Then, we decided that this research aims at identifying the fictional narratives addressed to contemporary Brazilian children and how reading, the book, the library and the librarian as mediator of reading are represented. In the second stage the same analysis with a similar sample of books written, edited and published in Argentina will be developed. The purpose is to have a comparative study because Brazil and Argentina, which are neighboring countries in South America, have different historic background since the 19th century, concerning the formulation of public policies of education, reading practices and formation of reader.

Firstly, it is necessary to draw a brief picture of the social and cultural environment in Brazil to understand the specific object of our interest. Despite Brazil being a country of continental dimensions and it being among the ten largest economies in the world it shows huge social inequality. On the other hand, Brazilian publishing market moves $U \$ 2.2$ billion yearly, with $35 \%$ of this total representing purchases by the federal government, for the provision of public and school libraries.

In addition to that, in general, Brazilian bookstores are concentrated in the most developed regions of the country and recent data report that Brazilians remain reading little, on average less than two titles per year.

In big cities, there are good elementary schools whose libraries are well planned and develop cultural activities in accordance with the guidelines of IFLA / UNESCO School Library Association. However, $9 \%$ of the population of the country remain illiterate and never went to school. Besides, it is important to consider that children entering school regularly, at the age of six, still find it difficult to fit within the literate world and to become readers in adulthood because they come from low-income families with low level of schooling. These families are considered as non-reader families.

Given this paradoxical portrait of Brazil in the beginning of the 21th century, our assumption when the research was started was that the representation of books and reading in children's literature would have a utilitarian function, supplementing an instructional role that the Brazilian families and schools fail to offer satisfactorily. That result, as will be shown in the end of this study, was only partially proved.

The criterion for sample selection was intentional or by judgment sampling, that is when the researcher assesses which Individuals (in this case, books) have more information about the topic being studied and chooses the elements the researcher thinks are the most relevant of the whole set to be investigated. The selected corpus built from queries to catalogs of publishers was composed of 10 Brazilian children's literature titles published from 1990 to 2013.

A content analysis of the texts and images of the selected corpus was carried out based on the concept of social representations argued by Serge Moscovici and from the way Brazilian researchers Regina Zilberman and Marisa Lajolo analyze the historical dimension of children's literature and of reading as a cultural and social practice. To analyze the representation of school library as it appears in some of the samples, we rely on the theoretical foundations of American researcher Carol Kuhlthau. 


\section{Analysis and results}

Numerous research papers in the field of social representation have shown that representation is never objectively neutral. In fact, in the set of 10 books reviewed the representation of reading is presented as a desirable social practice and is politically desired in all of them. The intention, explicit or not, of the writer and publisher of these books and government programs, which include them in its programs to promote reading, and of the school that has the students is none other than to influence in the formation processes of behavior of Brazilian children and youth, guiding their perceptions and expectations and causing them to build expected attitudes in relation to books and reading.

However, it cannot be said that this wave of books that show reading as a central or adjuvant theme constitute a homogeneous production. Indeed, the way of representing reading and the process of acquisition of reading habits varies to some extent. We found works that could be classified as legitimately literary, and that add maybe a little more than half of the sample reviewed; and we also found texts - $40 \%$ of the sample - which are to be literary but cannot disguise their pedagogical goals to lead children and adolescents to the practice of reading.

As an example of these two trends, there is this beautiful book of images and short text entitled Asas de Papel (Paper wings) which wanders about the limitless universe that reading opens up. On the other end the book Quem não lê não vê (Whoever does not read does not see) uses the theme of reading in a teenagers story, with the stated purpose of postulating rules - eleven steps, writes the author - for children and young people to learn how to enjoy reading .

In this second group of books, this pedagogy tradition of children's and youth literature genre continues rooted and, as it is known, since the 18th century it cultivates close ties of dependence between literature and school. In fact, the school and the school library recurrently appear in these books as the place of first contact with reading.

Contrarily, in the texts we with some risk call legitimately literary, reading happens in the private space, sometimes solitarily, sometimes shared with family members who are also readers. Anyhow, a central question underlies all the 10 works that choose reading as fictional theme and that represent reading positively.

This issue can be summarized in the sentence: how to make a reader? We identified at least three situations, which are sometimes more, sometimes less explicit, and that structure the narrative of the texts studied. They are:

\section{Transformation}

A person who does not like to read, or that reads uncritically, usually represented as an adult or teenager, becomes an aficionado reader after a privileged encounter with a stranger, especially a teacher, a librarian (Fome de ler, Quem não lê não vê). What is clear from these narratives and how reading is presented is the value of redemptive reading or reading as salvation.

\section{Inheritance}

The French side of sociology of reading, with Pierre Bourdieu, François de Singly and JeanClaude Pompugnac, among others, has made a substantial contribution to what they called 
cultural heritage. According to the authors, cultural heirs are those who receive in a literate family environment, an established cultural heritage, as well as the practices associated with it, and internalize them naturally reproducing the model of reader these heirs know since they were kids.

A book that fits in this group is Chorar é preciso? (Is it necessary to cry?)_by Tatiana Belinky, a Russian immigrant who came to Brazil at the age of eleven. Autobiographical type of work, the protagonist narrator is a girl who very early became a reader of fairy tales. She tells Brazilian children what it is like to "talk " with the books she have been told by her father, an inveterate reader, that every night used to tell her the most beautiful tales of Andersen.

Two other books discuss the inherited habit of reading by bringing situations that represent the nuance of Brazilian socio-cultural inequality. Morreu Tio Eurico, Rubião ficou rico (Uncle Eurico died, Rubião got rich) the protagonist, a simple worker in a small town receives as inheritance from a rich uncle - "hundreds, thousands of books." At first disappointed because he expected to receive a big sum of money, Rubião recovers and meets a new passion: the passion of reading. Another book entitled Lá no alto (Up there) takes the inheritance of a symbolic estate, the reading practice transmitted by the school, not explicitly but only poetically suggested: it is the story of a poor little girl who becomes fascinated with books that are up there on the bookcase in her rich teacher's home. Those books will never be hers but they roused her desire to read. The text ends just saying that the books would never leave that child's mind, just suggesting in one last illustration that she will become a reader.

In the three stories in which the main theme of the narrative is love for reading that passes from one generation to another, what leads the representation can be defined as reading as inherited and / or shared value.

\section{The institutional mediation}

The school librarian appears in three different stories as an important character in the fictional plot. In all of them, the librarian is seen by children and adolescents, at first, with strangeness and curiosity. In the book entitled Quem era ela? (Who was she?) three students try to understand what makes this strange person at school and then they struggle to pronounce that hard word: li.brar.i.an.

Along with this path of lack of knowledge of the function of the school and public library by some students, there is also Uma aventura biblioteconomica (A library adventure) and Guerra na Biblioteca (War in the library). In these two books, librarians are compared to witches because of the strange things they apparently do with the books in that environment which is so different from the classroom.

However, predictably, in the end of the story the librarians always reveal themselves as surprising people whose most extraordinary magic will be to turn people who do not like books into passionate readers.

In this group of stories, the clear intention is to introduce cultural institutions such as the School Library and Public Library and their educational functions to a large number of Brazilian children and adolescents. The Librarian appears as the main mediator of a student / 
library desired relationship. In this representation, the idea of reading as enabler for academic success and social prestige is implicit.

A finding that seems undeniable after analysis of this sample of books is that the apology to reading and the act of reading are present in all narratives cited, with arguments of philosophical-educational basis or only as a utilitarian issue.

On the one hand, we know that is not the function of literature as an art, to convince the reader of something, even if it is towards the consumption of literature for literary sake, as in these books addressed to children and adolescents. Thus, narratives that are led by a more aesthetic aspect than by a pedagogical one makes an apology of reading. This argument is not free but instead it gives "a legitimate need for the fictional universe", paraphrasing another Brazilian researcher (Ceccantini, 2004), who reviewed a sample of Brazilian literary books for adolescents awarded by different institutions.

On the other hand, if the main function of social representation is to influence the processes of social communications and formation of new practices (Moscovici, 2003), it is no wonder that the child /youth literature genre, which has historically been linked to the function of education and socialization, takes advantage of its easy integration into school to represent an idealized image of reading and of the library role in the life of Brazilian children and teenagers.

Brazilian child /youth literature, as shown in this study, is seen as a privileged vehicle to take part of the great Brazilian challenge of changing a rarefied setting of readers and library regulars. For that reason, children books invest to impact in the representation transformative reading can cause in the neo-readers. In other words, these child /youth books purport to build their own readers by presenting them to literary reading and suggesting possibilities of reading in school life and in the life in general. In that sense, it is worth recalling that according to Moscovici representative activity is a mental process that takes an object or an idea that was far distant or absent and makes it familiar and present in the inner universe of the subject, or their social group.

Fair it is to say that in the last decades the Brazilian government has been facing the challenge of increasing the access to education and reading. A major step was the creation of a new public policy of reading, that is the National Plan of Books and Reading (PNLL), which is seeking to involve public institutions and civil society to achieve that big goal. However, this is not a simple task considering Brazilian historical paradoxes.

The Minister of Culture in the government of former President Lula, in 2006, to announce the National Plan of Books and Reading (PNLL) said:

"Needless to say that only 1.8 books read per capita / year is too little, nor that number come from a recent and problematic relationship with the book, as shown by several researchers, due to a number of important historical factors, such as the reality of many social inequalities." 
We proceed, then, exposing how the texts reviewed represent two aspects of the relationship of children and young people with reading. Those aspects are spaces for reading and subjects of reading.

The first important finding regarding places for reading is that reading rarely appears being performed in the institutional place of the school library or public library but almost always in the private place of home. It is also significant to highlight how school library appears in two of the books studied. In addition to that, in a third book Quem não vê não Lê (Whoever does not read does not see), it is significant that this library is not mentioned in a story that is especially focused on the reading of books requested by teacher to teen students.

A similar narrative device in the four texts is that the story begins by showing a negative image of reading or of the school library through the speech of young students. In Quem era ela?" (Who was she?) in the first scene there are three students trying to guess who that kind of weird woman is, wearing round glasses, who looks like an owl, headed to the "room with bookshelves"!

After all, a boy says, "that room had been closed so long. What was inside it was a mystery. We only know that it was used to store books." In the book titled Guerra na biblioteca (War in the library) the complaint of adolescent students is that the school library looks like a playroom or children's party place and only appeals to small children at very young age. It is for that reason that the history teacher takes them to search on the public library.

In the previously mentioned book Quem não lê não vê ( Whoever does not read does not see) the first page starts with adolescent anguish because the teacher had asked students to read a 120 pages novel in the summer holidays.

Only in a book, Uma aventura biblioteconômica (A library adventure) the school library works from the beginning of the story as it should, following the standards suggested by contemporary studies that suggest that space as a place of research, interaction, reflection and encouragement for reading, integrated to the political-pedagogical project of the school. In this book, a boy who is fascinated by the mysterious figure of the librarian lives an adventure between the digital information technology and his fascination for books. However, it subtlety depicts the little familiarity that school students have with the school library.

Similarly to novels or soap operas that begin with the girl and the boy hating each other up to the end when they fall in love, in the vast majority of these stories, the initial ignorance of what a library is for is developed with scenes of adventure and at the end the discovery of a place that has thousands of possibilities of information, fun and the possibility of social mobility.

In other words, the most common representation of the school library in Brazilian youth literature is of an area that has to be discovered by the students so that it meets their cultural formation, as promised by librarianship academics.

Apparently, this representation of the school library in the literature is intended to be a supposed reflection of the reality of a country that is modernizing and that created a federal law a few years ago to enable all Brazilian schools with a school library. Yet, the nationwide 
study Portraits of Reading in Brazil, 2012, which aims at evaluating the behavior of the Brazilian reader, reveals that the library, both the school and the public is still little sought by Brazilians as a way to access the book.

Other important evidence found in this study is that the library, any library, is just a place to compulsory study and compulsory research for $71 \%$ of Brazilians who responded to the survey in all Brazilian regions. Other possibilities of access to literary and informational reading or other cultural activities are not mentioned while the public library is mentioned in only one book, Guerra na biblioteca (Albergaria, 1993, p.24).

Based on what the librarian said, the specificity of the place is known: "Here is a public place. Everyone has the right to attend a library. Most like to read. But there are lonely people [...] who simply adopted the place." Maybe she wanted to remember the UNESCO proposition to the universality of public that the public library should meet, but with a bit of humor, the author includes among goers of a public library in a large Brazilian city, Belo Horizonte, an old woman who is just knitting, a lunatic, an old and eccentric researcher. We are already referring to the subjects of reading. In this sense it should be noted, in most of the books reviewed, a dialectical movement between the non-reader, which is the one who opens more than half of the stories and the reader idealized by public policies of reading, composing the happy ending of all those fictional stories and reading readers.

Contemporary studies on sociology and history of reading present a typology of readers ranging from weak reader to strong reader, from disoriented reader to the competent reader, or even the ideal reader or model to the real reader of every culture and historical context.

As shown in this study, child /youth literature uses this taxonomy to represent an evolution that is urgent and necessary for the Brazilian citizen in the 21st century. Thus, the competent reader who appears in the stories reviewed is usually the teacher, the librarian, the father, the grandfather or other family member. Rare are the cases in which children and adolescents are depicted as already being readers and book lovers but, as was presented earlier, they will undergo a transformation throughout story.

The figure of the school librarian, who is always female, is important character in three of the stories although in one of these plots the librarian of the public library is highlighted by her professional competence, beauty and charisma in opposition to the impaired performance of the librarian school.

A curiosity is that these three stories the school librarian is compared to a witch, either by their physical appearance, reinforcing an already outdated stereotype about the profession, either by its mysterious activities which are unknown to children and young people who know little about the institution. See some examples:

\section{Quem era ela? (Who was she?)}

[...] Since day one at school, the door [in that room] was closed. Just now, the young woman wearing glasses came out. [...] For a moment, I imagined [...] that woman hiding deep down into the room, stirring a black cauldron, eager to get a child to her charm or even to throw into the cauldron. (Albergaria, 1993, p.6) 
And in Guerra na biblioteca (War in the library)

Etelvina was the school librarian. She was loved by kids and hated by adolescents. [...] Small children loved the stories she used to tell. She had delusions of horror stories and used to wear costumes for presentations. She would put black clothes on, a pointy hat and was the witch itself. (Albergaria, 1995, p.2)

And also, in Uma aventura biblioteconômica (A library adventure):

Juninho, a student from the school, believes Magali, the librarian, is a witch because besides having a strange and mysterious magical look and gestures she was unbelievably able to persuade people. Magali wanted to be a modern version of Don Quixote's Dulcinea, riding a motorcycle, with helmet and armor, flying at traffic lights. (Rios, 1993, p. 8)

It is interesting to note the recurrence use of an intertextuality form, which is, when a book refers to other literary texts on the figure of the competent reader and of the reader mediator of reading that appear in different situations in the books studied.

Those readers, who love reading literature and want to transfer that value to others, try by heart, to remember the most significant titles explicitly citing them in contact with the intended readers, or by using metaphors that signal to the classic works of world literature.

In the books reviewed in which the aesthetic intention is predominant, the quotation of the classics is justified because it suggests a link between the beginner reader and the great community of readers of the cultural tradition. In other books, in which we note the pedagogy representation of reading, a tendency to make the canonical literature sacred is observed and it consisted of literature that is often cited but little read, in fact, even by teachers and librarians.

It is not by chance, then, that Cervantes' Don Quixote, a work that has appeared in the top rankings of the most important literary works of world literature, is mentioned with reverence by librarians of two different stories.

Regarding the representation of social classes, only two books appear in secondary level as lower classes representatives. They are described as individuals who have some relationship with books but not exactly through reading. In all the books studied readers are middle class elements with sparse references to wealthy individuals who had collections of books who let them as inheritance or as a gift to family. Such representation dialogues with other data of the above-mentioned study Portraits of Reading in Brazil. In fact, $56 \%$ of respondents of the survey, equivalent to 99.3 million Brazilians never bought books in life, either because books are expensive, or due to a lack of interest in the practice of reading.

\section{Conclusion}

To conclude let us take UNESCO propositions on the fundamental conditions for a country to be considered a reader society: the book should be in a privileged place in the national imagination; there should be reader families; school should know how to form readers.

Well, it can be said that being in the second decade of this century we are halfway towards the society of information and reading. Yes, we have a good quality education system, with 
good schools and well equipped libraries, where high-level professionals working. We also have an editorial production of children's literature books of excellent quality and huge bookstores that satisfy the most discerning readers.

Nevertheless, we are still a paradoxical country, rich and poor at the same time, modern and archaic, urban and rural. Paralleling to a developed Brazil there is a deep and obscure Brazil as a great national writer once wrote, with high illiteracy rate and lack of libraries. In this scenario, even children who start school regularly at the age of six find it difficult to fit within the literate world and to become readers in adulthood because they come from low-income families with no or low level of education (or cultural capital). In that underdeveloped social environment there is a clear contradiction between considering reading as a condition of social and cultural rise, and at the same time do not having minimum requirements - both family and school - to promote independent reading which gives the reader-subject conditions to critically interact with the world.

In the context of this unequal map of the country, it is easier to understand the results of this research. In fact, $40 \%$ of the books reviewed are still tied to a utilitarian speech to serve the creation of a national imaginary about the individual and social value of reading and the development of a professional almost unknown by many - the librarian who is the mediator of reading. But even among those texts that carry a strong educational bias, it is possible to find - in the positive representation they make of reading - support for a formative itinerary that so many Brazilian children perform with effort. The good news is that the other $60 \%$ seem to be very good works at an aesthetic level, as for the text and or for the illustration the point of view.

In general, these books successfully escape from the trap of didacticism and present to Brazilian children and youngsters the world of books and reading in a thought-provoking and problematizing way.

We end with a quote from a Brazilian writer Ana Maria Machado who in 2000 was given the IBBY Hans Christian Andersen Award as the best author of children and youth literature: "I do not think anyone can teach someone else to read literature. Rather, I am convinced that what a person transmits the other is the revelation of a secret: the love for literature. It's more a contagion than teaching." (Machado, 2003 p.14).

\section{References}

Assunção, J. (2003). Retrieved April 4 , 2014, from http://www.revista.agulha.nom.br/ag34assuncao.htm

CBL/BRACELPA/ABRELIVROS. ( 2012). Retratos da leitura no Brasil. São Paulo.

Ceccantini, João Luís C. T. (2004). In Paulino, G. (Org.) Democratizando a leitura: pesquisas e práticas. Belo Horizonte: Autêntica, p. 81-96.

Fraisse, E.; Pompugnac, J.-C.; Poulain, M. (1997). Representações e imagens da leitura. São Paulo: Ática, p.57-96. 
Kuhlthau, C. C. (1999). O papel da biblioteca escolar no processo de aprendizagem. In Vianna, M.; Campello, B.; Moura, V. H. V. Biblioteca escolar: espaço de ação pedagógica. Belo Horizonte: EB/UFMG, p. 9-14.

Lajolo, M. \& Zilberman, R. (1996). A formação da leitura no Brasil. São Paulo, Ática.

Machado, A. M.\& Montes, G. (2003). Literatura infantil; creación, censura y resistência. Buenos Aires: Sudamericana.

Moscovici, Serge. (2003). Representações sociais: investigações em psicologia social. 4. ed. Petrópolis, RJ: Ed. Vozes.

Valente, P. Gurgel. (2013). Os dois Brasis. Retrieved April 10, from http://opiniaoenoticia.com.br

\section{Sample Reviewed}

Albergaria, Lino de. (1991) Quem era ela? II. Rosa Schettino. Belo Horizonte: Ed. Lê.

Albergaria, Lino de. (1993). II. Fábio Moraes. Guerra na biblioteca. São Paulo: Atual.

Belinky, Tatiana. (2001) II. Graça Lima. Chorar é preciso. São Paulo: Paulus.

Betancur, P. (2006). II. Mário T. G. Amaral. 2. ed. Quem não lê não vê. São Paulo: DCL.

Bocheco, E. (2012) II. Walther M. Santos. Casa de consertos. São Paulo: Melhoramentos.

Castanha, Marilda. (1999). 2 ed. O rei da fome. Rio de Janeiro: Ediouro.

Parreiras, N. ( 2011). II. Luiz Maia. Lá no alto. Curitiba: Positivo.

Sypriano, Lilian. (1993). II. Claudio Martins. Morreu Tio Eurico, Rubião ficou rico. Belo Horizonte: Formato Editorial.

Rios, Maria da Graça. (1993). II. Ângela Leite de Souza. Uma aventura biblioteconômica Belo Horizonte: Ed. Lê.

Xavier, Marcelo.(1993). Asa de papel. Belo Horizonte: Formato.

\section{Biographical notes}

Maria da Conceição CARVALHO holds a degree in Library Science as well as a Masters on Information Science and a PhD in Literary Studies from the Universidade Federal de Minas Gerais . She is a professor at the School of Information Science, UFMG. Her current interests as a researcher are focused on Reading and training of the reader, School Library and Publishing of Youth and Children's books . 
Alexandra Santana DA SILVA is a librarian since january 2014 and has worked at Santo Antônio School as school librarian from jan. 2013 to jan. 2014. Her interest as a researcher is focused on School Library studies.

Tatiane Meire CAMPOS is a School Librarian at a Municipal Public School (Elementary Education) in Belo Horizonte, MG. 